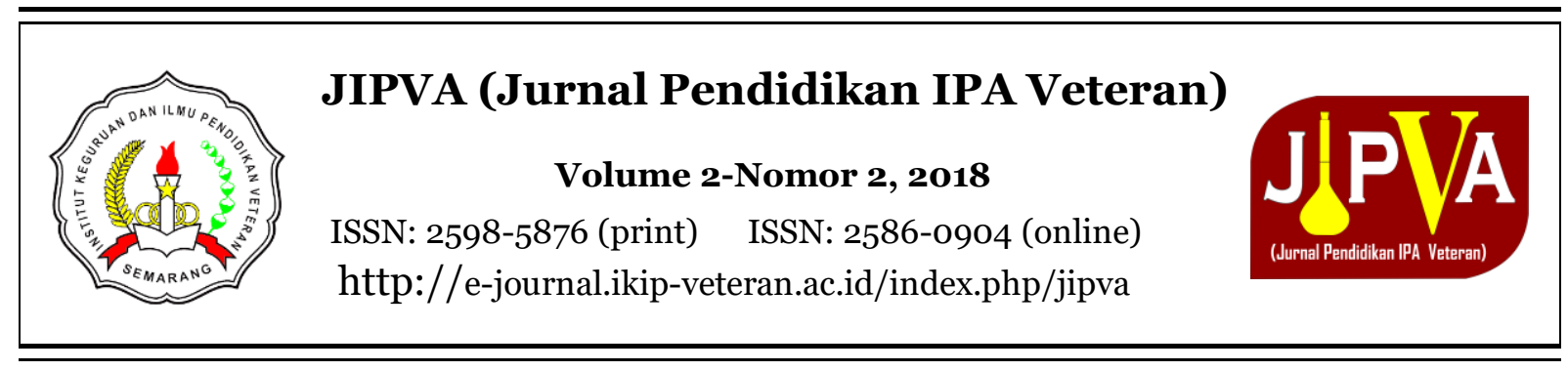

\title{
Pengembangan LKS Berbasis Project Based Learning untuk Meningkatkan Keterampilan Proses Sains Siswa SMP
}

\author{
Zaroah Dwi Fajriyanti ${ }^{1}$, Tias Ernawati ${ }^{2}$, Sigit Sujatmika ${ }^{3}$ \\ Program Studi Pendidikan IPA, Universitas Sarjana Wiyata Tamansiswa, Indonesia \\ *Corresponding author email: tias.ernawati@ ustjogja.ac.id
}

Received: 24 September 2018; Revised: 21 Oktober ; Accepted: 22 Oktober 2018

\begin{abstract}
Abstrak
Penelitian ini bertujuan untuk: 1) menghasilkan Lembar Kerja Siswa (LKS) berbasis Project Based Learning (PjBL) pada materi konsep energi dan sumber energi guna meningkatkan keterampilan proses sains siswa kelas VII SMP, 2) mendeskripsikan kualitas LKS berbasis PjBL yang dikembangkan. Penelitian ini termasuk penelitian pengembangan dengan model pengembangan 4D. Teknik pengumpulan data menggunakan instrumen penilaian untuk beberapa reviewer. Teknik analisis data menggunakan analisis kualitas LKS. Berdasarkan penilaian dosen ahli, peer reviewer, dan guru IPA diperoleh skor rata-rata 141,9 dengan persentase keidealan $81,1 \%$ menyatakan bahwa kualitas LKS Sangat Baik. Hasil tanggapan siswa diperoleh skor rata-rata 75 dengan persentase keidealan 88,2\% menyatakan bahwa kualitas LKS Sangat Baik. Dapat disimpulkan bahwa LKS yang dikembangkan layak digunakan dalam pembelajaran.
\end{abstract}

Kata Kunci: Keterampilan Proses Sains, Pengembangan LKS, Project Based Learning.

\section{Developing The Student's Worksheet Based on Project Based Learning to Improve Student Science Process Skills on Junior High School}

\begin{abstract}
This research was aimed to: 1) produced a student's worksheet based on project based learning on concept of energy and energy resources material to improve he student's science process skills in seven grade of Junior High School, 2) described the quality of student's worksheet based on project based learning was developed. This research is include research and development with $4 D$ models. Data collection technique used assessment instrument for reviewers. Data analysis technique used analysis quality of student's worksheet. According to assessment of expert lecturer, peer reviewer, and natural science teacher got an average score of 141,9 with ideal presentage of $81,1 \%$ stated that the quality of student's worksheet was very good. The result of students respons got an average score of 75 with ideal percentage of $88,2 \%$ stated that the quality of student's worksheet was very good. In conclusion that the student's worksheet had been developed was feasible to implement on the lesson. Keywords: Science Process Skills, Developing Student's Worksheet, Project Based Learning.
\end{abstract}

How to Cite: Fajriyanti, Z., Ernawati, T., \& Sujatmika, S. (2018). Pengembangan LKS Berbasis Project Based Learning untuk Meningkatkan Keterampilan Proses Siswa SMP. JIPVA (Jurnal Pendidikan IPA Veteran), 2(2), 149-161. doi:10.31331/jipva.v2i2.691 


\section{PENDAHULUAN}

Proses pembelajaran IPA yang sesuai dengan Kurikulum 2013 dilaksanakan dengan menekankan scientific approach (pendekatan saintifik) (Uswatun \& Rohaeti, 2015). IPA tidak hanya berupa kumpulan fakta tetapi juga proses perolehan fakta yang didasarkan pada kemampuan menggunakan kemampuan dasar IPA, hal tersebut juga mendasari perlu adanya pemberian pengalaman belajar secara langsung melalui penggunaan dan pengembangan keterampilan proses dan sikap ilmiah (Kemendikbud, 2014).

Penerapan keterampilan proses siswa dalam pembelajaran dapat meningkatkan keterlibatan siswa dalam pembelajaran sehingga dapat memicu mereka untuk menemukan sendiri fakta dan konsep yang dipelajarinya, mengembangkan pikiran, serta dapat memahami secara lebih mendalam (Saputri \& Dewi, 2014). Pendekatan keterampilan proses siswa juga dapat melatih kemampuan siswa baik secara intelektual, manual, dan sosial, sehingga pengalaman belajarnya semakin bermakna (Putri \& Widiyatmoko, 2013). Berdasarkan teori perkembangan kognitif Piaget siswa SMP yang berada pada kisaran usia 11-14 tahun berada pada tahap operasional formal (Setyaningsih \& Wijayanti, 2018). Pada tahap ini siswa mulai mampu melakukan pemecahan masalah. Melalui keterlibatan siswa dalam memecahkan suatu permasalahan dalam pembelajaran, maka siswa akan berpikir secara maksimal dan mengaktifkan potensi dirinya sehingga proses pembelajaran lebih hidup dan bermakna (Sujatmiko, 2016).

Namun kenyataan di lapangan, guru belum mengoptimalkan pembelajaran untuk mengembangkan keterampilan proses sains siswa. Guru IPA belum banyak menerapkan model-model yang inovatif sehingga siswa kurang terlibat secara langsung keterlibatan siswa kurang terlihat. Bahan ajar IPA juga kurang variatif dan belum mengakomodasi siswa untuk dapat memecahkan masalah.

Berdasarkan permasalahan di atas, dapat diidentifikasi bahwa perlu adanya pengembangan suatu bahan ajar dengan menggunakan model pembelajaran yang mampu meningkatkan keterampilan proses sehingga siswa mampu meningkatkan kemandiriannya selama pembelajaran. Salah satu bahan ajar yang dapat digunakan yaitu Lembar Kerja Siswa (LKS). Bahan ajar cetak ini dapat berupa petunjuk atau langkah-langkah untuk melakukan praktikum maupun tugas teoritis (Daryanto \& Dwicahyono, 2014; Majid, 2013). Penggunaan LKS memiliki manfaat dan tujuan sebagai berikut: 1) mengefektifkan siswa dalam proses pembelajaran, 2) membantu siswa dalam mengembangkan konsep, 3) sebagai pedoman bagi guru dan siswa dalam melaksanakan pembelajaran, 4) membantu guru dalam menyusun pembelajaran yang efektif, dan 5) membantu siswa dalam menambah informasi tentang konsep yang dipelajari melalui kegiatan belajar secara sistematis (Barokah, 2016). LKS disusun untuk melatih kemandirian belajar siswa sebagai cermin dari sikap kreatif, kebebasan dalam bertindak, dan tanggung jawab yang ditandai dengan adanya inisiatif belajar serta keinginan mendapatkan pengalaman baru (Prastowo, 2012; Safitri \& Budhi, 2017). Oleh karenanya, penggunaan LKS dalam pembelajaran mampu melatih kemandirian belajar siswa melalui tugas-tugas yang harus dikerjakan.

LKS sesuai tuntutan Kurikulum 2013 harus dapat mengembangkan berbagai keterampilan ilmiah siswa pada proses pembelajaran yaitu berdasar pendekatan scientific (Handayani \& Aljani, 2018). Oleh 
karenanya, dalam pengembangan LKS ini digunakan basis dari Project Based Learning (PjBL). PjBL merupakan suatu pendekatan yang memperkenankan siswa bekerja secara mandiri untuk membangun pengetahuannya dalam pembelajaran dan mewujudkannya dalam produk nyata, hasilnya kemudian dipresentasikan (Ladyana, 2014). The George Lusac Educational Foundation (Kemendikbud, 2014). menyebutkan tahapan PjBL terdiri dari: 1) Start With the Essential Question (Ajukan Pertanyaan), 2) Design a Plan for the Project (Rancang Rencana Proyek), 3) Creat a Schedule (Susun Jadwal), 4) Monitor the Student and the Progress of the Project (Pantau Siswa dan Kemajuan Proyek), 5) Asses the Outcome (Penilaian Hasil), 6) Evaluation the Experience (Evaluasi Pengalaman). Dengan mengimplementasikan tahapan atau sintaks PjBL ke dalam sistematika LKS yang dibuat, diharapkan keterampilan proses siswa dapat ditingkatkan melalui tugas proyek yang tersedia.

Keterampilan proses sains dikelompokan menjadi 2, yaitu keterampilan proses dasar (basic skills) yang terdiri atas kegiatan mengobservasi, mengklasifikasi, memprediksi, mengukur, menyimpulkan, mengkomunikasikan, dan keterampilan proses terpadu (integrated skills) meliputi, identifikasi variabel sampai dengan yang paling kompleks yaitu eksperimen (Duruk, Akgün, Doğan, \& Gülsuyu, 2017). Adapun keterampilan proses yang perlu dilatihkan secara terus-menerus pada siswa kelas VII SMP dalam pembelajaran IPA diantaranya, melakukan pengamatan, menginferensi, dan mengkomunikasikan (Kemendikbud, 2014). Sebagai seorang calon saintis, keterampilan proses sains merupakan bekal yang tidak dapat dipisahkan dari pembelajaran bagi siswa (Hasyim, 2018). Dengan demikian, dalam LKS berbasis PjBL ini dirancang sedemikian rupa untuk meningkatkan keterampilan proses dasar untuk siswa kelas VII SMP tersebut. Pengembangan LKS berbasis $\mathrm{PjBL}$ juga memperhatikan materi yang sesuai untuk diterapkan yaitu energi dan sumber energi. Dengan demikian, maka tujuan penelitian ini yaitu untuk menghasilkan LKS berbasis PjBL yag layak digunakan dalam pembelajaran IPA pada materi konsep energi dan sumber energi untuk meningkatkan keterampilan proses siswa kelas VII SMP dan untuk mendeskripsikan kualitas dari LKS berbasis PjBL yang dikembangkan berdasarkan penilaian oleh beberapa pakar.

\section{METODE}

\section{Jenis Penelitian}

Penelitian ini merupakan penelitian pengembangan menggunakan model pengembangan 4D.

\section{Waktu dan Tempat Penelitian}

Penelitian ini dilaksanakan selama 6 bulan yaitu dari tanggal 6 November 2017 sampai dengan 3 Mei 2018 pada semester genap, tahun ajaran 2017/2018. Penelitian ini dilakukan di SMP Negeri 2 Sewon, SMP Negeri 3 Sewon, dan SMP Negeri 4 Sewon, Bantul, Yogyakarta.

\section{Prosedur}

Prosedur penelitian ini menggunakan model pengembangan 4D (Define, Design, Develop, Disseminate) yang dibatasi pada tahap develop (Diani, 2015). LKS berbasis PjBL yang dikembangkan ini bertujuan untuk memfasilitasi siswa dalam mengerjakan tugas proyek berupa pembuatan kincir angin 
sebagai pembangkit listrik sederhana. Waktu pengerjaan tugas proyek ini yaitu $2 \mathrm{x}$ pertemuan (5 JP), dimana pembagiaannya dijelaskan di dalam LKS yang disusun sedemikian rupa hingga pada akhirnya siswa mampu menyelesaikan tugas proyek dengan menghasilkan produk berupa kincir angin. Aspek keterampilan proses yang diintegrasikan dalam penelitian ini yaitu keterampilan proses dasar antara lain mengobservasi, mengklasifikasi, memprediksi, mengukur, menyimpulkan, mengkomunikasikan (Duruk et al., 2017). Prosedur penelitian dalam pengembangan LKS disajikan dalam Gambar 1.

\section{Teknik Pengumpulan Data}

Teknik pengumpulan data dalam penelitian ini adalah wawancara dan kuesioner. Wawancara dilakukan kepada guru IPA SMP untuk memperoleh berbagai informasi yang dibutuhkan dalam mengembangkan LKS ini, diantaranya mengenai kurikulum yang digunakan di sekolah, bagaimana karakter siswa kelas VII, bagaimana kebutuhan akan bahan ajar yang dapat menunjang pembelajaran. Sementara itu, untuk lembar angket yang digunakan sebagai alat untuk menentukan kualitas LKS yang dikembangkan diberikan kepada masing-masing reviewer dengan menyesuaikan waktu dan tempat yang telah ditentukan.

\section{Teknik Analisis Data}

Data kualitatif berupa masukan, koreksi, saran, dan kritik yang diberikan oleh dosen pembimbing, dosen ahli, peer reviewer, dan guru IPA SMP terhadap LKS hasil pengembangan ini diseleksi relevansinya oleh peneliti, dan saran yang dianggap relevan selanjutnya digunakan sebagai bahan revisi LKS. Data yang diperoleh dengan teknik kuesioner/angket ini dianalisis dengan teknik analisis deskriptif. Data kualitatif yang berupa pernyataan sangat baik, baik, cukup, kurang, dan sangat kurang diubah menjadi data kuantitatif berupa skor penilaian, yaitu $\mathrm{SB}=$ $5, \mathrm{~B}=4, \mathrm{C}=3, \mathrm{~K}=2, \mathrm{SK}=1$. Dan data kualitatif berupa pernyataan sangat setuju, setuju, kurang setuju, tidak setuju, dan sangat tidak setuju diubah menjadi data kuantitatif berupa skor penilaian, yaitu SS = $5, \mathrm{~S}=4, \mathrm{KS}=3$, TS $=2$, $\mathrm{STS}=1$. Skor terakhir yang diperoleh dikonversikan lagi menjadi tingkat kelayakan produk secara kualitatif. Konversi skor rata-rata menjadi nilai menurut Widoyoko (2009) disajikan dalam Tabel 1 sebagai berikut:

Tabel 1. Kriteria Kategori Penilaian Ideal

\begin{tabular}{|c|c|c|}
\hline Rentang Skor & Nilai & Kriteria \\
\hline $\begin{array}{c}\mathrm{Mi}+1,5 \mathrm{SBi} \leq \bar{X} \leq \text { skor } \\
\text { maksimum ideal }\end{array}$ & A & $\begin{array}{l}\text { Sangat } \\
\text { Baik }\end{array}$ \\
\hline $\begin{array}{c}\mathrm{Mi}+0,5 \mathrm{SBi} \leq \bar{X} \leq \mathrm{Mi}+ \\
1,5 \mathrm{SBi}\end{array}$ & B & Baik \\
\hline $\begin{array}{c}\mathrm{Mi}-0,5 \mathrm{SBi} \leq \bar{X} \leq \mathrm{Mi}+ \\
0,5 \mathrm{SBi}\end{array}$ & $\mathrm{C}$ & $\begin{array}{l}\text { Cukup } \\
\text { Baik }\end{array}$ \\
\hline $\begin{array}{c}\mathrm{Mi}-1,5 \mathrm{SBi} \leq \bar{X} \leq \mathrm{Mi}- \\
0,5 \mathrm{SBi}\end{array}$ & $\mathrm{D}$ & $\begin{array}{c}\text { Kurang } \\
\text { Baik }\end{array}$ \\
\hline $\begin{array}{c}\text { Skor Minimum ideal } \leq \bar{X} \\
\leq \mathrm{Mi}-1,5 \mathrm{SBi}\end{array}$ & $\mathrm{E}$ & $\begin{array}{c}\text { Sangat } \\
\text { Kurang } \\
\text { Baik }\end{array}$ \\
\hline
\end{tabular}

Keterangan:

$$
\begin{aligned}
\bar{X}= & \text { mean ideal } \\
\mathrm{Mi}= & \frac{1}{2} \text { (skor maksimum ideal }+ \text { skor } \\
& \text { minimum ideal }) \\
\mathrm{SBi}= & \left(\frac{1}{2}\right)\left(\frac{1}{3}\right) \text { skor maksimum ideal }- \text { skor } \\
& \text { minimum ideal })
\end{aligned}
$$




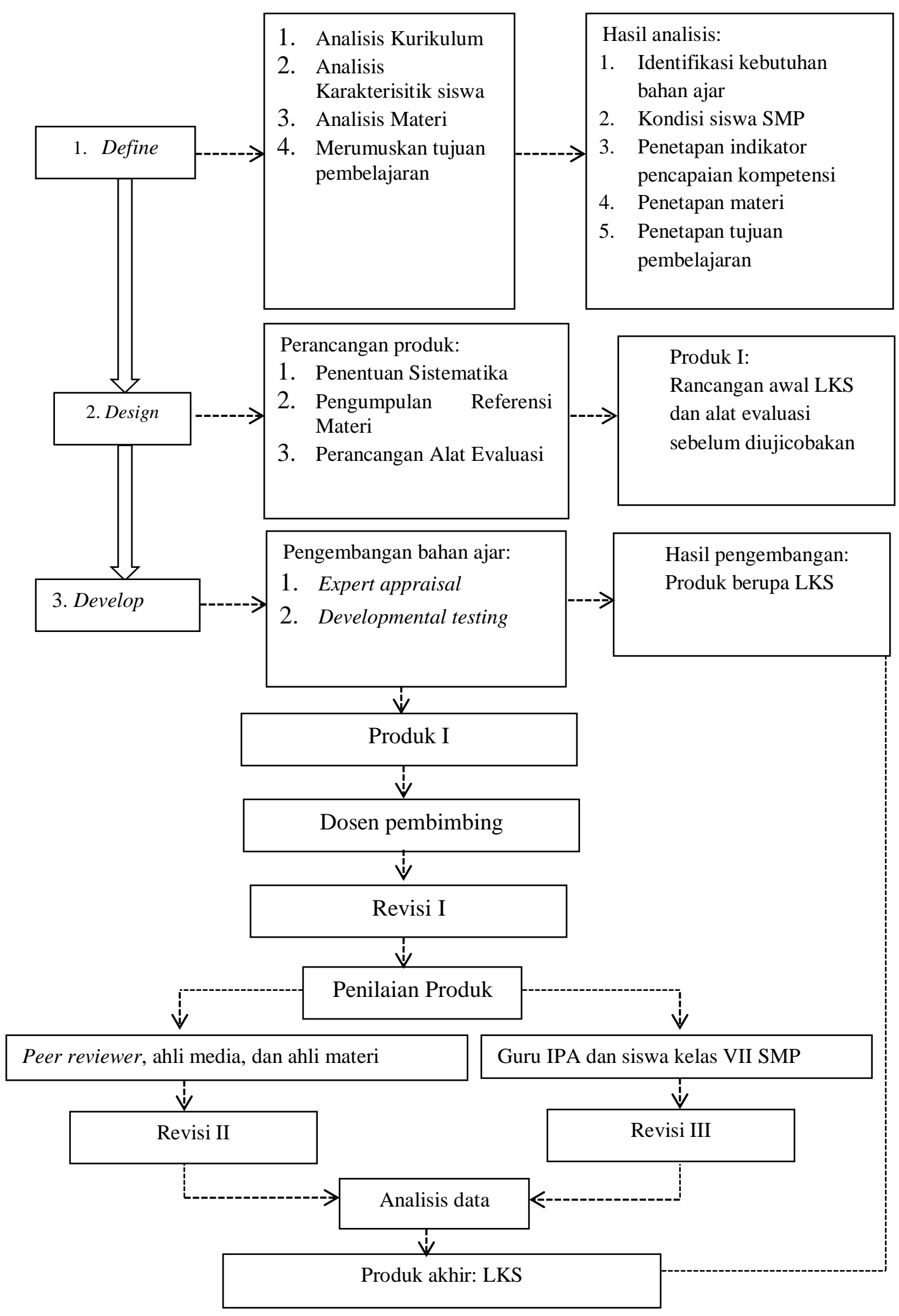

Gambar 1. Desain Pengembangan LKS 
Skor maksimum ideal $=\sum$ butir kriteria $\mathrm{x}$ skor tertinggi

$\begin{aligned} \text { Skor minimum ideal }= & \sum \text { butir kriteria } \\ & \text { x } \quad \text { skor } \\ & \text { terendah }\end{aligned}$

Dalam mengidentifikasi hasil reviewer, peneliti menggunakan lima kategori yaitu: sangat baik, baik, sedang, kurang, dan sangat kurang. Pengidentifikasian yang dilakukan dengan menggunakan ketentuan sebagai berikut (Arikunto, 2007):

Tabel 2. Skala Persentase Penilaian Keidealan Kualitas Produk

\begin{tabular}{ccc} 
No. & Interval & Kriteria \\
1. & $81 \%-100 \%$ & Sangat Baik \\
2. & $61 \%-80 \%$ & Baik \\
3. & $41 \%-60 \%$ & Sedang \\
4. & $21 \%-40 \%$ & Kurang \\
5. & $0 \%-201 \%$ & Sangat Kurang \\
\hline
\end{tabular}

Dalam penelitian pengembangan ini ditetapkan nilai kelayakan produk minimal dengan kategori B (Baik). Jika skor rata-rata penilaian oleh ahli materi, ahli media, maupun guru IPA SMP minimal B (Baik) maka produk media yang dikembangkan sudah dianggap efektif dan layak untuk digunakan.

\section{HASIL DAN PEMBAHASAN}

\section{Pengembangan Lembar Kerja Siswa} Berbasis Project Based Learning

Penelitian pengembangan ini telah menghasilkan produk berupa LKS berbasis PjBL pada materi konsep energi dan sumber energi untuk meningkatkan keterampilan proses siswa kelas VII SMP. LKS hasil pengembangan ini dapat digunakan sebagai bahan ajar yang inovatif yang sesuai dengan Kurikulum 2013 dalam memfasilitasi guru dan siswa selama proses pembelajaran IPA. Terdapat tugas proyek tentang pembuatan kincir angin sebagai pembangkit listrik sederhana yang mampu mengembangkan keterampilan proses dan kreativitas siswa dalam menyelesaikan tugas tersebut. Berikut beberapa gambar komponen yang terdapat dalam LKS yang dikembangkan. Gambar halaman sampul LKS hasil pengembangan ditunjukkan dalam Gambar 2.

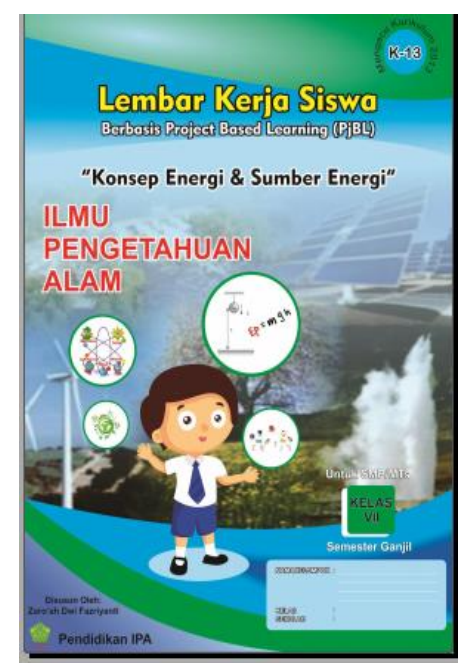

Gambar 2. Halaman Sampul LKS

Kelebihan dari LKS ini dibandingkan dengan LKS pada umumnya yaitu tampilannya dibuat dengan perpaduan warna dan desain yang menarik untuk meningkatkan minat baca siswa, tugas-tugas yang harus dikerjakan siswa dirancang dengan menerapkan keterampilan proses dasar. LKS ini dilengkapi dengan instrumen penilaian berupa penilaian kognitif, penilaian afektif, penilaian proses/kinerja (keterampilan), penilaian produk, dan penialian laporan yang dapat membantu guru dalam mengukur keberhasilan belajar siswa selama pembelajaran menggunakan LKS hasil pengembangan ini.

Tahapan pengembangan LKS berbasis PjBL yaitu menggunakan model pengembangan 4D, tahapan yang telah dilakukan yaitu define, design, develop dan disseminate. Pada tahap develop dilakukan expert appraisal berupa validasi produk oleh pakar dan developmental testing yaitu penilaian produk oleh praktisi. Penilaian 
terhadap LKS yang dikembangkan didasarkan pada aspek penilaian menurut BSNP (2012) yang meliputi aspek kelayakan isi, aspek bahasa, aspek penyajian, dan aspek kegrafisan. Contoh isi dalam LKS disajikan dalam Gambar 3.
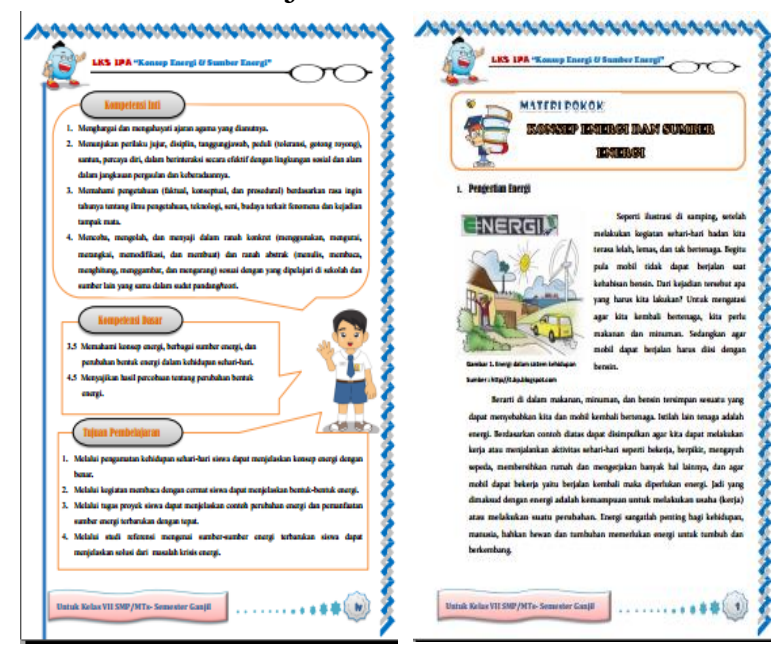

Gambar 3. Contoh Isi dalam LKS

\section{Validasi oleh Pakar}

Validasi oleh pakar dilakukan oleh dosen ahli (ahli materi dan ahli media) dan peer reviewer. Proses validasi ini dilakukan dengan menggunakan angket untuk menilai kualitas LKS serta memberikan saran dan masukan yang dapat dijadikan bahan perbaikan terhadap LKS yang dikembangkan. Aspek penilaian terdiri dari aspek penilaian yang diadopsi dari BSNP (2012)dan terdapat aspek tambahan sehingga meliputi aspek kelayakan isi, aspek bahasa, aspek penyajian, aspek kegrafisan, kesesuaian dengan sintaks PjBL, dan kelengkapan komponen LKS. Ahli media dan materi memberikan komentar dan saran terhadap LKS yang dikembangkan selanjutnya dijadikan sebagai dasar perbaikan. Komentar dan tahap tindak lanjut disajikan pada Tabel 3.

Tabel 3. Hasil Tindak Lanjut Komentar dan Saran dari Dosen Ahli

\begin{tabular}{|c|c|c|}
\hline No. & Komentar dan Saran & Tindak Lanjut \\
\hline \multirow[t]{2}{*}{1} & Pada cover ditambah kalimat "berbasis & Pada cover sudah ditambah kalimat \\
\hline & Project Based Lerning (PjBL) & "berbasis Project Based Lerning (PjBL) \\
\hline 2 & $\begin{array}{l}\text { Substansi dari tugas proyek diubah } \\
\text { menjadi penjabaran kegaiatan pada setiap } \\
\text { sintaks PjBL }\end{array}$ & $\begin{array}{l}\text { Substansi dari tugas proyek sudah diubah } \\
\text { menjadi penjabaran kegaiatan pada setiap } \\
\text { sintaks PjBL }\end{array}$ \\
\hline \multirow[t]{2}{*}{3} & Kalimat pada LKS dibuat lebih & Kalimat pada LKS sudah dibuat lebih \\
\hline & $\begin{array}{l}\text { komunikatif yang disesuaikan dengan } \\
\text { tingkat berpikir siswa SMP }\end{array}$ & $\begin{array}{l}\text { komunikatif yang disesuaikan dengan } \\
\text { tingkat berpikir siswa SMP }\end{array}$ \\
\hline 4 & $\begin{array}{l}\text { Alat evaluasi untuk penilaian kognitif } \\
\text { mencakup materi yang dijabarkan dalam } \\
\text { LKS }\end{array}$ & $\begin{array}{l}\text { Alat evaluasi untuk penilaian kognitif } \\
\text { sudah mencakup materi yang dijabarkan } \\
\text { dalam LKS }\end{array}$ \\
\hline 5 & $\begin{array}{l}\text { Instrumen penilaian proses disesuaikan } \\
\text { dengan sintaks } \mathrm{PjBL}\end{array}$ & $\begin{array}{l}\text { Instrumen penilaian proses sudah } \\
\text { disesuaikan dengan sintaks } \mathrm{PjBL}\end{array}$ \\
\hline 6 & $\begin{array}{l}\text { Tampilan/desain LKS dibuat lebih } \\
\text { menarik }\end{array}$ & $\begin{array}{l}\text { Tampilan/desain LKS sudah dibuat lebih } \\
\text { menarik }\end{array}$ \\
\hline 7 & $\begin{array}{l}\text { Masih terdapat kesalahan penulisan pada } \\
\text { LKS }\end{array}$ & $\begin{array}{l}\text { Kesalahan penulisan pada LKS sudah } \\
\text { diperbaiki }\end{array}$ \\
\hline 8 & $\begin{array}{l}\text { Belum menjelaskan keterkaitan ilustrasi } \\
\text { gambar dengan prinsip melakukan usaha }\end{array}$ & $\begin{array}{l}\text { Sudah ditambah kaliamat yang } \\
\text { menjelaskan keterkaitan ilustrasi gambar }\end{array}$ \\
\hline
\end{tabular}


9 Keterangan rumus ditulis dengan huruf miring

10 Terdapat kalimat yang kurang kontradiktif

11 Terdapat kalimat yang kurang nyambung dengan isi paragraph

12 Pada kompetensi dasar kata "termasuk fotosintesis" dihilangkan karena tidak berkaitan dengan kegaiatan yang akan dilakukan

13 Sebaiknya sumber gambar berasal dari buku atau situs web resmi

14 Daftar pustaka disusun berdasarkan abjad

15 Keterampilan proses mengamati dan menerapkan perlu diperjelas pada tugas yang dikerjakan siswa

16 Jika tabel terpotong maka pada halaman berikutnya diberi nama (kepala) table

17 Pada tabel hasil monitoring bisa ditambah satu spasi tiap baris

18 Perlu disediakan lembar kerja yang berisi evaluasi pengalaman dan refleksi dengan prinsip melakukan usaha

Keterangan rumus sudah ditulis dengan huruf miring

Kalimat sudah dibuat menjadi lebih kontradiktif

Sudah dilakukan perbaikan terhadap kalimat yang kurang nyambung dengan isi paragraph

Kata "termasuk fotosintesis" sudah dihilangkan sehingga menjadi KD 3.5

Memahami konsep energi, berbagai sumber energi, dan perubahan bentuk energi dalam kehidupan sehari-hari,

Sumber gambar sudah ditambahkan dari buku

Daftar pustaka sudah disusun berdasarkan abjad

Tugas atau pertanyaan yang harus dikerjakan siswa yang merupakan penerapan keterampilan proses mengamati dan menerapkan sudah dibuat menjadi lebih jelas dan komunikatif untuk memudahkan pemahaman siswa Tabel yang terpotong pada halaman berikutnya sudah diberi kepala tabel

Tiap baris pada tabel monitoring sudah ditambahkan satu sapasi

Kegiatan mengevaluasi pengaman dan refleksi sudah disediakan lembar kerjanya
Sementara itu penilaian oleh peer reviewer meliputi keseluruhan aspek penilaian yaitu aspek kelayakan isi, aspek bahasa, aspek penyajian, dan aspek kegrafisan, kesesuaian dengan sintaks PjBL, dan kelengkapan komponen LKS. Adapun komentar secara umum yang diberikan peer reviewer terhadap LKS yang di kembangkan yaitu untuk tata tulis dan penyajian materi lebih ditata kembali sehingga lebih menarik untuk dibaca dan secara keseluruhan LKS sudah bagus dan mudah dimengerti.

\section{Penilaian oleh Praktisi}

Penilaian oleh praktisi dilakukan oleh guru IPA dan siswa kelas VII SMP sebagai pengguna dari LKS yang dikembangkan. Guru IPA memberikan penilaian terhadap keenam aspek yang sama dengan peer reviewer. Selain memberikan penilaian terhadap kualitas LKS guru IPA juga memberikan komentar dan saran, yang kemudian dilakukan tindak lanjut terhadap komentar dan saran tersebut. Hasil tindak lanjut berdasarkan komentar dan saran guru IPA seperti terlihat pada Tabel 4. 
Tabel 4. Hasil Tindak Lanjut Komentar dan Saran dari Guru IPA

\begin{tabular}{|c|c|c|}
\hline No. & Komentar dan Saran & Tindak Lanjut \\
\hline 1 & $\begin{array}{l}\text { Alokasi waktu disesuaikan } \\
\text { dengan tingkat kemampuan } \\
\text { berpikir siswa }\end{array}$ & $\begin{array}{l}\text { Alokasi waktu untuk pengerjaan tiap-tiap lembar } \\
\text { kerja sudah diberi tambahan waktu dengan } \\
\text { menyesuaikan kemampuan berpikir siswa }\end{array}$ \\
\hline 2 & $\begin{array}{l}\text { Perlu penambahan materi yang } \\
\text { lebih lengkap mengenai kincir } \\
\text { angin }\end{array}$ & $\begin{array}{l}\text { Materi mengenai kincir angin sudah lebih } \\
\text { lengkap untuk menambah wawasan siswa }\end{array}$ \\
\hline 3 & Ditambah penilaian laporan & $\begin{array}{l}\text { Instrumen penilaian sudah ditambahkan dengan } \\
\text { penilaian laporan }\end{array}$ \\
\hline 4 & $\begin{array}{l}\text { Keterangan pada rumus satuanya } \\
\text { lebih diperjelas }\end{array}$ & $\begin{array}{l}\text { Satuan untuk tiap-tiap besaran pada rumus tetap } \\
\text { ditulis di dalam tanda kurung karena sudah } \\
\text { dianggap jelas }\end{array}$ \\
\hline 5 & $\begin{array}{l}\text { Pada bunyi hukum kekekalan } \\
\text { energi ditambah kata "hanya" }\end{array}$ & $\begin{array}{l}\text { Bunyi hukum kekekalan energi sudah } \\
\text { ditambahkan kata "hanya" }\end{array}$ \\
\hline 6 & $\begin{array}{l}\text { Keterampilan proses mengamati } \\
\text { dan menerapkan yang ada pada } \\
\text { LK.1 pertanyaan yang harus } \\
\text { dijawab siswa supaya diberi } \\
\text { option }\end{array}$ & $\begin{array}{l}\text { Pertanyaan atau tugas yang harus dikerjakan } \\
\text { siswa yang merupakan penerapan keterampilan } \\
\text { proses mengamati dan menerapkan pada LK.1 } \\
\text { sudah diberi option untuk memudahkan } \\
\text { pemahaman siswa }\end{array}$ \\
\hline 7 & $\begin{array}{l}\text { Keterampilan proses mengamati } \\
\text { pada LK. } 2 \text { pertanyaan yang harus } \\
\text { dijawab siswa supaya diberi } \\
\text { option }\end{array}$ & $\begin{array}{l}\text { Pertanyaan atau tugas yang harus dikerjakan } \\
\text { siswa yang merupakan penerapan keterampilan } \\
\text { proses mengamati pada LK.2 sudah diberi option } \\
\text { untuk memudahkan pemahaman siswa }\end{array}$ \\
\hline 8 & $\begin{array}{l}\text { Ada beberapa kesalahan } \\
\text { penulisan dan penggandaan kata }\end{array}$ & $\begin{array}{l}\text { Kesalahan penulisan dan penggandaan kata sudah } \\
\text { diperbaiki }\end{array}$ \\
\hline 9 & $\begin{array}{l}\text { Penggunaan multimeter belum } \\
\text { dipelajari di kelas VII }\end{array}$ & $\begin{array}{l}\text { Penggunaan multimeter pada kegiatan uji coba } \\
\text { produk sudah dihilangkan karena belum dipelajari } \\
\text { di kelas VII }\end{array}$ \\
\hline 10 & $\begin{array}{l}\text { Perlu perbaikan kalimat motivasi } \\
\text { yang ada pada LKS }\end{array}$ & $\begin{array}{l}\text { Kalimat yang berisi motivasi pada LKS sudah } \\
\text { diperbaiki sesuai dengan saran yang diberikan }\end{array}$ \\
\hline 11 & $\begin{array}{l}\text { Masih terdapat kesalahan } \\
\text { pengetikan pada LKS }\end{array}$ & Kesalahan pengetikan sudah diperbaiki \\
\hline 12 & $\begin{array}{l}\text { Peta konsep sebaiknya dibuat } \\
\text { sesuai yang ada pada buku guru }\end{array}$ & $\begin{array}{l}\text { Peta konsep materi mengenai konsep energi dan } \\
\text { sumber energi sudah disesuaikan dengan peta } \\
\text { konsep yang ada pada buku guru }\end{array}$ \\
\hline 13 & $\begin{array}{l}\text { Hiasan berupa garis putus-putus } \\
\text { lebih nyaman dilihat bila } \\
\text { garisnya utuh }\end{array}$ & $\begin{array}{l}\text { Hiasan berupa garis putus-putus yang ada pada } \\
\text { LKS sudah diganti dengan garis untuh supaya } \\
\text { lebih nyaman dilihatnya }\end{array}$ \\
\hline 14 & $\begin{array}{l}\text { Pada format laporan antara alat } \\
\text { dan bahan sebaiknya dipisahkan } \\
\text { penempatanya }\end{array}$ & $\begin{array}{l}\text { Perintah untuk menuliskan alat dan bahan yang } \\
\text { ada pada laporan merancang alat sudah } \\
\text { dipisahkan penempatan alat dan bahannya }\end{array}$ \\
\hline 15 & $\begin{array}{l}\text { Perlu diperhatikan penskoran } \\
\text { pada penilaian kognitif siswa } \\
\text { disesuaikan dengan kesulitan } \\
\text { atau kedalaman berpikir siswa } \\
\text { pada tiap soal }\end{array}$ & $\begin{array}{l}\text { Penskoran pada penilaian kognitif siswa sudan } \\
\text { diganti dan disesuaikan dengan kesulitan atau } \\
\text { kedalaman berpikir siswa pada tiap soal }\end{array}$ \\
\hline
\end{tabular}

Hasil penilaian dari beberapa dan guru IPA) disajikan dalam Tabel reviewer (dosen ahli, peer reviewer, 5. Sementara itu, penilaian terhadap 
kualitas LKS yang dilakukan oleh kemampuan siswa Selain siswa hanya meliputi 4 aspek yaitu: aspek kelayakan isi, bahasa, penyajian, dan kegrafisan. Jumlah butir dan bahasa disesuaikan dengan

memberikan penilaian terhadap LKS yang dikembangkan, siswa juga memberikan komentar secara umum setelah membaca LKS tersebut.

Tabel 5. Hasil Penilaian Dosen Ahli, Peer Reviewer, Guru IPA

\begin{tabular}{llllll}
\hline No. & Aspek Penilaian & Butir & \multicolumn{3}{c}{ Hasil rata-rata penilaian } \\
\cline { 4 - 6 } & & & $\begin{array}{l}\text { Dosen } \\
\text { ahli }\end{array}$ & $\begin{array}{l}\text { Peer } \\
\text { reviewer }\end{array}$ & $\begin{array}{l}\text { Guru } \\
\text { IPA }\end{array}$ \\
& & & 22 & 26,6 & 25,3 \\
1 & Kelayakan isi & 6 & 14 & 16,4 & 16 \\
2 & Bahasa & 4 & 19 & 30,6 & 30 \\
3 & Penyajian & 7 & 21 & 22 & 21 \\
4 & Kegrafisan & 5 & 24 & 25 & 25 \\
5 & Kesesuaian dengan sintaks & 6 & & & \\
& PjBL & & 29 & 29,2 & 29,7 \\
6 & Kelengkapan komponen LKS & 7 & 129 & 149,8 & 147 \\
\hline
\end{tabular}

\section{Kualitas Lembar Kerja Siswa Berbasis} Project Based Learning

Kualitas LKS berbasis PjBL yang telah disusun dapat diketahui dengan cara menganalisis data yang diperoleh berdasarkan penilaian dari dosen ahli (ahli materi dan ahli media), peer reviewer, guru IPA, dan siswa kelas VII SMP. Analisis data yang dilakukan yaitu dengan mengubah data kualitatif yang diperoleh dari penilaian reviewer ke dalam bentuk data kuantitatif. Data kuantitatif tersebut kemudian ditabulasi dan dianalisis pada tiap aspek penilaian. Skor akhir yang diperoleh selanjutnya dikonversi menjadi data kualitatif berdasarkan kriteria kategori penilaian ideal.

\section{Kualitas LKS berdasarkan penilaian} dosen ahli, peer reviewer, dan guru IPA

Data yang diperoleh dari penilaian dosen ahli, peer reviewer, dan guru IPA seperti yang tertera pada tabel di atas akan diakumulasikan sehingga akan diperoleh kualitas LKS berdasarkan penilaian tiap-tiap

aspek oleh ketiga reviewer tersebut. Diagram keidealan LKS hasil penilaian oleh dosen, peer reviewer dan guru IPA disajikan dalam Gambar 4.

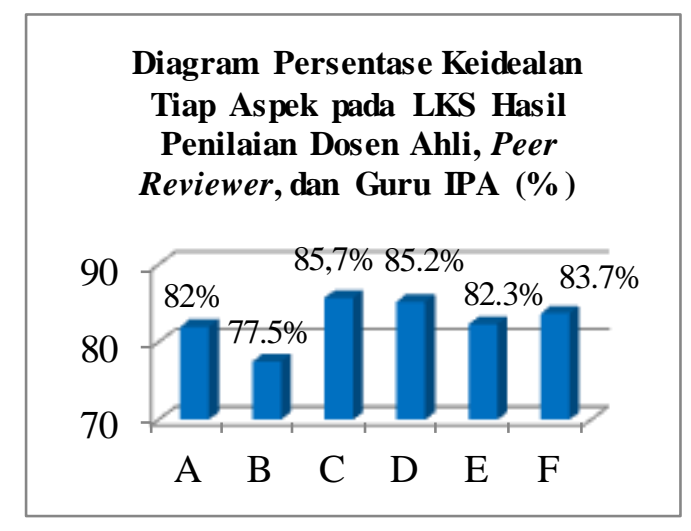

Gambar 4. Diagram Persentase Keidealan Tiap Aspek pada LKS A. Isi, B. Bahasa, C. Penyajian, D. Kegrafisan,

E. Kesesuaian dengan Sintaks PjBL,

F. Kelengkapan Komponen LKS

Berdasarkan Tabel 4 dapat diketahui bahwa kualitas LKS berbasis PjBL yang dikembangkan menurut penilaian dosen 
ahli, peer reviewer, dan guru IPA secara keseluruhan menyatakan "Sangat Baik" (A) dengan skor rata-rata sebesar 141,9 yang terletak pada rentang skor $140 \leq \bar{X} \leq 175$. Persentase keidealan terhadap penilaian LKS ini sebesar $81,1 \%$ terletak pada interval $81 \%$ - 100\% dengan kategori "Sangat Baik". Berdasarkan diagram yang tertera di atas dapat dilihat bahwa aspek penyajian memperoleh persentase keidealan tertinggi sebesar $85,7 \%$, sedangkan aspek yang memperoleh persentase terendah sebesar $77,5 \%$ yaitu aspek bahasa.

\section{Kualitas LKS berdasarkan penilaian siswa kelas VII SMP}

LKS berbasis PjBL untuk meningkatkan keterampilan proses siswa yang dikembangkan ini perlu dilakukan penilaian oleh siswa sebagai pengguna LKS tersebut. Adapun hasil penilaian keidealan LKS oleh siswa disajikan dalam Gambar 5.

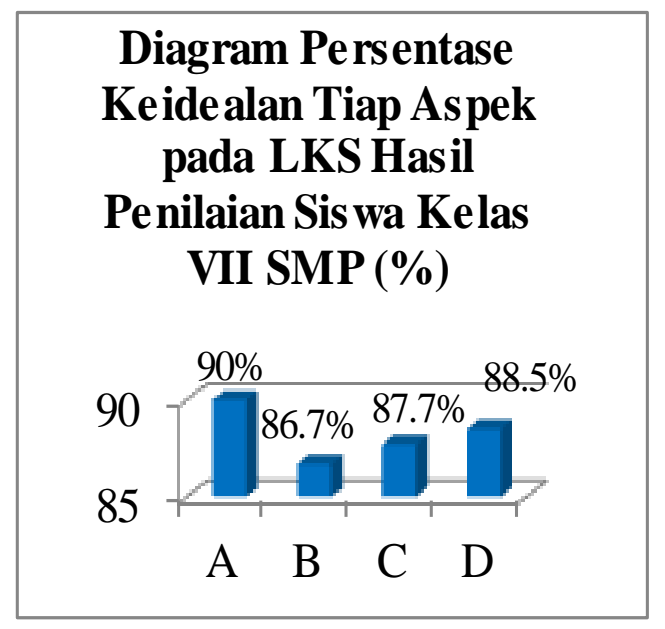

Gambar 5. Diagram persentase keidealan tiap aspek pada LKS hasil penilaian siswa , A.Isi, B. Bahasa, C.

Penyajian, D. Kegrafisan

Berdasarkan Tabel 5 dapat diketahui bahwa kualitas LKS berbasis PjBL yang dikembangkan menurut penilaian siswa kelas VII SMP secara keseluruhan menyatakan "Sangat Baik" (A) dengan skor rata-rata sebesar 75 yang terletak pada rentang skor $68 \leq \bar{X} \leq 85$. Persentase keidealan terhadap penilaian LKS ini sebesar $88,2 \%$ terletak pada interval $81 \%$ $100 \%$ dengan kategori "Sangat Baik". Berdasarkan diagram di atas menunjukan aspek penilaian yang memperoleh persentase tertinggi adalah aspek kelayakan isi dengan persentase keidealan 90\% termasuk kategori sangat baik. Aspek penilaian yang memperoleh persentase terendah adalah aspek bahasa dengan persentase keidealan sebesar $86,7 \%$.

Materi yang dipilih dalam penelitian ini diterapkan pada materi tentang konsep energi dan sumber energi kelas VII SMP semester ganjil sesuai dengan penelitian sebelumnya bahwa LKS berbasis PjBL sesuai jika diterapkan pada materi yang memiliki hubungan erat dengan lingkungan sekitar, karena siswa akan dihadapkan dengan permasalahan yang nyata terjadi dilingkungannya, dan diminta untuk memberikan alternatif penyelesaian (Ladyana, 2014). Selain itu, materi ini dipilih karena bersifat abstrak sehingga sulit dijelaskan dan dapat membantu guru dalam memfasilitasi pembelajarannya menjadi lebih berkualitas dan dapat menjadi alternatif bahan ajar dalam meningkatkan keterampilan proses siswa untuk memahami secara mendalam konsep IPA yang dipelajarinya.

Berdasarkan hasil penilaian oleh para reviewer (dosen ahli, peer reviewer, dan guru IPA) dan penilaian oleh siswa SMP kelas VII terhadap kualitas LKS yang dikembangkan secara keseluruhan memperoleh nilai A yang berarti sangat baik. Dengan demikian, maka LKS berbasis PjBL untuk meningkatkan keterampilan 
proses siswa kelas VII SMP yang dikembangkan ini layak digunakan. Beberapa penelitian terdahulu juga mengungkapkan bahwa penggunaan LKS maupun lembar kerja terbimbing dapat meningkatkan pemahaman konsep dan sikap ilmiah siswa dalam pembelajaran (Alfathy, Susanto, \& Marwoto, 2018)

\section{SIMPULAN DAN SARAN}

\section{Simpulan}

Media pembelajaran IPA dan lingkungan yang ada di sekolah yang terletak di Kecamatan Tambun Selatan, Kabupaten Bekasi, Jawa Barat, belum terlalu beragam. Para guru merasa kesulitan dalam mengembangkan media pembelajaran. Lambatnya proses pengembangan juga disebabkan guru tidak memiliki banyak waktu untuk mengembangkan media.

\section{Saran}

Kedepannnya harus dilakukan pengembangan media pembelajaran IPA dan Lingkungan dikarenakan masih sangat sedikit variasi media yang digunakan dalam pembelajaran.

\section{DAFTAR PUSTAKA}

Alfathy, R., Susanto, H., \& Marwoto, P. (2018). Penerapan aktivitas Aesop's berbantuan Guidance Worksheet untuk meningkatkan pemahaman konsep fisika dan sikap ilmiah. JIPVA (Jurnal Pendidikan IPA Veteran), 2(1), 48-57. https://doi.org/10.31331/jipva.v2i1.574

Barokah, H. (2016). Pengembangan LKS project based learning (PjBL) untuk melatih keterampilan proses sains (KPS) dan menumbuhkan sikap ilmiah siswa SMA. Universitas Negeri Lampung.

BSNP. (2012). Deskripsi butir instrumen penilaian buku teks pelajaran SMP, SMA, SMK, komponen kegrafikaan.

Daryanto, D., \& Dwicahyono, A. (2014). Pengembangan perangkat pembelajaran (silabus, RPP, PHB, bahan ajar). Yogyakarta: Gava Media.

Diani, R. (2015). Pengembangan perangkat embelajaran fisika berbasis pendidikan karakter dengan model problem based learning. Jurnal Ilmiah Pendidikan Fisika Al-Biruni, 04(2), 241-253. https://doi.org/10.24042/jpifalbiruni.v4 i2.96.

Duruk, U., Akgün, A., Doğan, C., \& Gülsuyu, F. (2017). Examining the Learning Outcomes Included in the Turkish Science Curriculum in Terms of Science Process Skills : A Document Analysis with Standards-Based Assessment. International Journal of Environmental \& Science Education, 12(2), 117-142.

Handayani, D. E., \& Aljani, A. (2018). Pengembangan lembar kerja berbasis pendekatan saintifik kelas IV sekolah dasar. Natural: Jurnal Ilmiah Pendidikan IPA, 5(1), 19-24.

Hasyim, F. (2018). Mengukur kemampuan berpikir analitis dan keterampilan proses sains mahasiswa calon guru fisika STKIP Al Hikmah Surabaya. JIPVA (Jurnal Pendidikan IPA Veteran), 2(1), 80-89. https://doi.org/10.31331/jipva.v2i1.591

Kemendikbud. (2014). Buku guru ilmu pengetahuan alam untuk SMP Kelas VIII. Jakarta.

Ladyana, B. (2014). Kelayakan teoritis LKS project based learning (PjBL) penggunaan bahan alternatif produk bioteknologi konvensional. Jurnal BioEdu Berkala Ilmiah Pendidikan Biologi, 3(3), 396-403.

Majid, A. (2013). Strategi pembelajaran. Bandung: Remaja Rosdakarya.

Prastowo, A. (2012). Panduan kreatif 
membuat bahan ajar inovatif. Yogyakarta: Diva Press. Yogyakarta: Diva Press.

Putri, B. K., \& Widiyatmoko, A. (2013). Pengembangan LKS IPA Terpadu berbasis inkuiri tema darah di SMP N 2 Tengaran. Jurnal Pendidikan IPA Indonesia, 2(2), 102-106.

Safitri, S. R., \& Budhi, W. (2017). Pengaruh model pembelajaran inkuiri terhadap hasil belajar IPA ditinjau dari kemandirian belajar siswa. Natural: Jurnal Ilmiah Pendidikan IPA, 4(2), 34-40.

Saputri, V. A. C., \& Dewi, N. R. (2014). Pengembangan alat peraga sederhana Eye Lens Tema Mata kelas VIII untuk menumbuhkan keterampilan peserta didik. Jurnal Pendidikan IPA Indonesia, 3(2), 109-115.
Setyaningsih, D. E. N., \& Wijayanti, A. (2018). The developing of simple props based on guided inquiry to improve student's critical thinking skills. Jurnal Pena Sains, 5(1), 1-10.

Sujatmiko, S. (2016). Pengaruh metode pembelajaran Problem Based Learning terhadap prestasi belajar ditinjau dari gaya belajar dan kemandirian. Jurnal Sosiohumaniora, 2(1), 116-123.

Uswatun, D. A., \& Rohaeti, E. (2015). Perangkat pembelajaran IPA berbasis inkuiri untuk meningkatkan critical thinking dan scientific attitude siswa. Jurnal Inovasi Pendidikan IPA, 1(2), 138-152.

Widoyoko, E. P. (2009). Evaluasi program Pembelajaran. Yogyakarta: Pustaka Pelajar. 